\title{
The American Family in Black and White: A Post-Racial Strategy for Improving Skills to Promote Equality
}

\author{
James J. Heckman \\ University of Chicago American Bar Foundation and University College Dublin
}

\begin{abstract}
In contemporary America, racial gaps in achievement are primarily due to gaps in skills. Skill gaps emerge early before children enter school. Families are major producers of those skills. Inequality in performance in school is strongly linked to inequality in family environments. Schools do little to reduce or enlarge the gaps in skills that are present when children enter school. Parenting matters, and the true measure of child advantage and disadvantage is the quality of parenting received. A growing fraction of American children across all race and ethnic groups is being raised in dysfunctional families. Investment in the early lives of children in disadvantaged families will help close achievement gaps. America currently relies too much on schools and adolescent remediation strategies to solve problems that start in the preschool years. Policy should prevent rather than remediate. Voluntary, culturally sensitive support for parenting is a politically and economically palatable strategy that addresses problems common to all racial and ethnic groups.
\end{abstract}

Disparities between Blacks and Whites are persistent features of American society. On many measures, Blacks as a group perform worse than Whites and the trends are not encouraging. These disparities are continuing reminders of America's troubled history of racial discrimination. They clash with American beliefs about equality, opportunity and social mobility.

What makes discussion of these disparities so painful is that in the past, American public policy has been so wrong. The institution of slavery, the all-too-slow dismantling of segregation in the South and discriminatory practices elsewhere, prevented ready acceptance of Blacks into the mainstream of American society. When America was finally goaded into abolishing state-sanctioned discrimination by the activities of the Civil Rights Movement, integration of African Americans into the economy accelerated. There was a surge in Black economic status in the late 1960s and early 1970s. Progress was especially rapid in the previously segregated South. ${ }^{1}$

Some 40 years later, despite the visible success of an elite group within the Black population, the economic and social progress of a large segment of African Americans has been painfully slow. If anything, the official statistics overstate the progress of African males. ${ }^{2}$ The success of the Civil Rights Movement in reversing discrimination on the books gave rise to the hope that active government policy in the economy, the schools, and in the courts could produce full equality in the larger society.

Why have these hopes not been realized? What can we learn from this stalled progress and how should public policy respond? Setting aside preconceived notions and examining the

James J. Heckman Department of Economics University of Chicago 1126 East 59th Street Chicago, Illinois 60637 (773) $702-0634$ jjh@uchicago.edu.

Supporting material for this paper is at the website http://jenni.uchicago.edu/understanding_b-w_gap/. 
body of evidence amassed since 1960, are the factors producing their slow economic and social progress unique to African Americans or are they the consequence of common forces that operate equally on all Americans?

Black America has a unique history and now faces unique challenges. Nonetheless, there is great wisdom in the insight of William Julius Wilson ${ }^{3}$ that the first order problems facing African Americans in contemporary society are shared by many other groups. In particular, the shortfalls in achievement in the $21^{\text {st }}$ century stem from shortfalls in skills, not in the rewards accorded those skills. Skills include education and on the job training as well as cognitive and personality traits.

Unskilled persons of all races and ethnicities are challenged by common global economic forces that cannot easily be reversed. Secular trends in trade and technology have boosted the demand for skilled labor and the supply of skills has not kept pace. The percentage of Americans graduating college is the highest in history. At the same time, the high school dropout rate, properly counted, has increased in the past 40 years. ${ }^{4}$ American society is dividing into affluent haves and disadvantaged have nots, with skills primarily determining advantage and disadvantage. For Americans of all racial and ethnic groups, the supply of skills has responded slowly to shifts in market demand. The response is particularly slow for African American males.

President Lyndon Johnson recognized the importance of skills when he launched the War on Poverty around the same time he promoted the 1964 Civil Rights Act. Our understanding of the skills that are important and the strategies that are effective in fostering them has improved greatly since that time. Many of the programs and policies designed to boost skills that were launched in the 1960s War on Poverty failed. ${ }^{5}$ However, people continue to advocate many of these unsuccessful approaches, especially those most concerned about closing racial gaps. Just as we need to rethink the sources of racial inequality in contemporary American society, we need to rethink our strategies for promoting skills.

Public policy to promote skills has to reckon with three essential truths distilled from a large body of research conducted in the wake of the War on Poverty. First, the skills needed for success in life are multiple in nature. Success requires more than cognition and smarts. Soft skills are important. Conscientiousness, perseverance, sociability, and other character traits matter a lot, even though they are largely neglected in devising policies to reduce inequality.

Second, skill formation is a dynamic, synergistic process. Skills beget skills. They cross foster and promote each other. A perseverant child open to experience learns more. Early success fosters later success. Advantages cumulate. Young children are flexible and adaptable in ways that adolescents and adults are not. It is much easier to prevent deficits from arising in the early years than to remediate them later. The War on Poverty took a shotgun, scattershot, approach to fostering the skills of disadvantaged persons of all ages and stages of development. Its policies did not target the years when interventions to promote skills are most effective.

Third, families play an essential role in shaping the skills of their children. Skill formation starts in the womb. The early years of a child's life before the child enters school lay the foundations for all that follows. Large gaps in abilities between the advantaged and the disadvantaged open up early before children enter school. Unequal as they are, American schools do little to widen or narrow these gaps. The family plants and nourishes the seed that grows into the successful student and adult. Families in jeopardy produce children in jeopardy who often grow into adults who fail to realize their potential. We know much more about the powerful role of the family in shaping adult skills than we did in the 1960s. 
Across all race and ethnic groups, the American family is under strain. ${ }^{6}$ This fact has substantial implications for the skills of the next generation because of the crucial role families play in shaping the early lives of children. Currently, over $40 \%$ of all American children are born out of wedlock and more than $12 \%$ of all children live in families where the mother has never married. Such families provide fewer financial and parenting resources for child development. It is well documented that the children of lone parent families perform worse in life on many outcomes. ${ }^{7}$ Any effective policy to foster skills has to recognize the importance of the family, the mechanisms through which families create child skills and the stress under which many families operate.

When the Moynihan report on the state of the African American family was written, roughly $26 \%$ of all African American children were born out of wedlock. ${ }^{8}$ The figure is now $72 \%$. A venomous reception greeted Moynihan's analysis. He was falsely charged with "blaming the victim" because he pointed out the adverse consequences of out of wedlock birth for children. For years it was politically incorrect to discuss the family as a contributor to Black disparity. Fortunately, and due in no small part to the writings of William Julius Wilson, it is now possible to have honest discussions of this delicate issue. ${ }^{9}$

Moynihan used strong language and focused exclusive attention on "the pathology of the Negro family," an unfortunate choice of words that obscured an important insight. It is now recognized that the warnings raised by Moynihan apply more generally to all American families. Dysfunctional families are on the rise in many quarters of American society. They often produce dysfunctional children. They are major contributors to inequality in contemporary society.

Understanding that in 2011 the problems facing many African Americans are also the problems facing many other Americans, reframes the policy discussion and helps us move past traditional flash points. Many American children across all races and ethnicities are in the same sinking boat.

Policies that recognize the importance of the early years, the central role of the family in producing skills, and the importance of skills other than those measured by achievement tests are likely to be far more effective than current school-based strategies and adolescent remediation programs. Policies based on these three essential truths prevent, rather than remediate, problems. They bolster schools by assisting families in creating and supporting successful students. They relieve the burden on other social institutions by creating more capable and achievement-motivated youth.

Strategies that address inequality by recognizing the common problems facing all Americans shift the dialogue about disparity beyond racial boundaries. Such strategies are much more likely to gain widespread political support than race-based policies.

We need to learn from the mistakes of the programs launched by the War on Poverty so that we can implement effective programs that recognize the powerful role of the family and the early years in shaping the skills that matter. In an era of massive government deficits at all levels, strategies for promoting skills must be cost-effective. They need to harness all of the resources in the private sector to promote skills, including the love of mothers for their children.

This essay proceeds as follows. I first summarize a substantial body of evidence that shows that discrimination in the labor market is no longer a first order cause of racial disparity. I then discuss the skill gap: which skills matter and the important role that the family plays in producing those skills. I then consider the consequences of adverse trends in American families that retard skill formation and create widening inequality between the advantaged 
and disadvantaged. Effective policies to supplement the resources of disadvantaged families are proposed. The true measure of child poverty is parenting, and an effective skills policy bolsters the parenting resources of the disadvantaged.

\section{Overt Discrimination is No Longer a First Order Problem in American Society}

Discrimination exists and should be eliminated. The evidence suggests, however, that discrimination in the reward to skills is not the primary driver of the achievement gap in contemporary America. At this moment, inequality in skills is the first order problem.

The skills persons bring to the market, to school and to other quarters of society, determine their success. So do the rewards to those skills. In the labor market, wages are the rewards to skills. One group can have lower wages than another because payments per unit skill are lower, because their skills are lower or because both factors operate. What is the relative importance of each factor? Recent research addresses this question.

The columns labeled "actual" in Table 1 show the percentage shortfalls in hourly wages of all employed Blacks and Hispanics compared to the wages of all employed Whites. To gauge if disparity in wages is a uniquely African American experience, I compare their shortfalls with those of Hispanics. A negative number denotes a shortfall. Black males earn $25 \%$ less than White males. Hispanic males earn $15 \%$ less than White males. The corresponding figures for females are $17 \%$ lower wages for Blacks and $7 \%$ lower wages for Hispanics. The gaps in annual earnings are generally larger because minorities tend to be employed fewer hours. ${ }^{10}$ These gaps are large and statistically significant, that is, they are not likely to arise solely by chance.

This pattern of disparity is replicated in many other measures of social and economic achievement: schooling, health, incarceration, occupational success. ${ }^{11}$ Blacks and Hispanics have worse outcomes than Whites in American society. Furthermore, Blacks on average fare worse than Hispanics.

Are these disparities due to pervasive labor market discrimination or to gaps in skills? These two interpretations of the evidence in Table 1 (and their counterparts for other outcomes, presented in the web appendix) have profoundly different implications for public policy. If persons of identical skill are treated differently in the market on the basis of race or ethnicity, a more vigorous enforcement of civil rights and affirmative action policies would be warranted. If, on the other hand, the gaps are due to the skills that people bring to the labor market, then policies that foster skills should be emphasized.

To resolve this issue, I adjust adult wages by scores on scholastic ability tests measured in the teenage years. ${ }^{12}$ (See the columns labeled "adjusted" in Table 1.) After adjustment, the gaps substantially diminish for Black males and are essentially zero for Hispanic males. The gaps actually reverse for females - that is, adjusting for their ability, minority females earn more than their White counterparts. (A positive number means that on average the abilityadjusted wages of minorities are higher than those of Whites.)

There are gaps in educational attainment as well. High school dropout rates are higher for minorities and a smaller proportion of them attend and graduate college. See the evidence in Table 2. In this table, the proportion of Blacks entering college is 12 points lower than that of Whites. For Hispanics, the figure is 14 points.

Adjusting for their differences in scholastic ability with the same measure of scholastic ability used to adjust wages in Table 1, Blacks are 16 points more likely to go to college and 
Hispanics are 15 points more likely. After accounting for differences in adolescent ability, family income in the college going years and tuition costs play only minor roles in explaining the gaps. ${ }^{14}$

Any serious accounting of economic and social disparities must reckon with the importance of skills in American society. ${ }^{15}$ Saying this does not deny the validity of a variety of studies that show discriminatory inclinations in the labor market by firms. America is not yet a color blind society. However, discrimination at the individual level is different from discrimination at the group level, although these concepts are often confused.

Racial discrimination is present if an otherwise identical person is treated differently by virtue of that person's race, and race has no direct effect on productivity. Audit pair studies identify racial discrimination in sampled firms by sending auditors with equal qualifications of different races and ethnicities to apply for jobs. They show evidence of pervasive discrimination. ${ }^{16}$

Finding discrimination by race or gender at a randomly selected firm does not provide an accurate assessment of the discrimination that takes place in realized market transactions. ${ }^{17}$ People sort in the labor market. Minorities avoid bigots and are hired by the less-bigoted firms. Measured wages reflect this sorting. The impact of market discrimination on wages is not determined by the most discriminatory participants in the market, or even by the average level of discrimination among firms, but rather by the level of discrimination at the firms where ethnic minorities or women actually end up working. Numerous studies that document discrimination by audit pair methods do not detect the margin at which market transactions actually occur.

Thus there is no conflict between the discrimination reported in numerous audit studies and the small gap in ability-adjusted wages. Blacks constitute roughly $12 \%$ of the U.S. population. If $12 \%$ or more of the jobs are at nondiscriminating or slightly discriminating firms, the contribution of discrimination to overall wage gaps would be small.

This is not to say that minorities do not face unfair situations regarding bigotry or to downplay the real costs of locating nondiscriminating employers. But unequal reward to skills is not the first order explanation for observed gaps in racial achievement in contemporary American society. Any serious attack on the problem of racial and ethnic disparity in American society has to address disparity in skills. ${ }^{18}$

\section{Gaps in Skills}

The data reveal an uncomfortable fact. Minority abilities as a group are generally lower than those of White abilities. The gap is quite pronounced for the measure of scholastic ability used to adjust wages and schooling in Tables 1 and 2. ${ }^{19}$

One response to racial and ethnic disparities in test scores is that the tests are culturally biased. However, a large literature refutes such claims. ${ }^{20}$ The tests used to make the adjustments in Table 1 predict performance in a number of activities for all race and ethnic groups.

The test scores reflect in part the differences in the years of schooling attained at the time people take the test. Minorities generally have lower levels of schooling when they take the test and hence get lower test scores. Accounting for this disparity does not change the main message of Table 1-that it is gaps in skills not gaps in payments to skills that determine the lion's share of racial wage disparity. ${ }^{21}$ 
It is sometimes claimed that expectations of discrimination in the labor market substantially reduce the educational aspirations of African American parents for their children and of the children for themselves. The evidence shows otherwise. ${ }^{22}$

Some have argued that a large portion of the gap in test scores between minorities and Whites is due to "stereotype threat." Convincing evidence shows that minority students who are told that the tests they are taking are being used to compare the abilities of minorities with those of Whites perform worse on such tests compared to tests administered without such framing. ${ }^{23}$

The test used to produce the evidence in Tables 1 and 2 does not frame the exam in the way that produces stereotype threat. In addition, the quantitative importance of the stereotype threat in accounting for test score gaps is slight. ${ }^{24}$ The test score gaps between minorities and majorities are real and they measure something that matters for performance in economic and social life, although by no means do they estimate all that is important.

\section{Gaps in Soft Skills}

Most discussions of racial and ethnic achievement gaps focus on measures of scholastic ability. Indeed, for many analysts, the achievement gap is only about differences in scores on tests of scholastic ability. This emphasis reflects a broad consensus in American society about the value of achievement tests that are used to monitor the success and failure of schools and students in schools. The No Child Left Behind program has pushed this focus to what some have described as a mania. The program has created a culture of teaching to the test in schools, with consequent neglect of the subjects and byproducts of schooling that are not tested. ${ }^{25}$

An emerging body of evidence shows that, as is intuitively obvious and commonsensical, more than book learning, or the smarts measured by achievement tests, is required for success in life. ${ }^{26}$ As Woody Allen put it: "Eighty percent of success is showing up." 27 While the cognitive skills measured by achievement tests are powerful predictors of life success, so are socio-emotional skills-sometimes called "soft skills" or character traits. These involve motivation, sociability (the ability to work with and cooperate with others), attention, self regulation, self esteem, the ability to defer gratification and the like. Good schools and functional families produce soft skills as well as cognitive skills. ${ }^{28}$ For many outcomes, soft skills are as predictive, if not more predictive, of schooling, wages, participation in crime and participation in healthy behaviors as cognitive skills. ${ }^{29}$ There is evidence that disadvantaged children of all race groups have lower levels of soft skills. ${ }^{30}$

\section{The Early Emergence of Skill Gaps}

Gaps in skills between the advantaged and the disadvantaged emerge at early ages and persist. Figure 1 shows achievement scores by age for White children classified by their mother's education, a measure of the social advantage of the child. More educated mothers marry more educated men, have access to more financial resources for their children, and provide their children with nurturing and supportive environments than do less educated women. ${ }^{31}$

There are two noteworthy features of this figure. First, gaps in achievement test scores by social background of the child are substantial. The test score gap between more educated Whites and less educated Whites is about the same as the gap in the test scores between Blacks and Whites. Second, the gaps arise early and persist. Schools do little to budge these gaps even though the quality of schooling attended varies greatly across social classes. ${ }^{33}$ Much evidence tells the same story as Figure 1. Gaps in test scores classified by social and 
economic status of the family emerge at early ages, before schooling starts, and they persist. ${ }^{34}$ Similar gaps emerge and persist in indices of soft skills classified by social and economic status. ${ }^{35}$ Again, schooling does little to widen or narrow these gaps. ${ }^{36}$

\section{Biology and Genetics}

Genetic determinists would argue that heritability of genes explains the performance of children and the environments provided to them by their parents. They would interpret Figure 1 as showing the power of genes in perpetuating inequality across the generations.

In The Bell Curve, Richard Herrnstein and Charles Murray implicitly attribute Black-White gaps in scholastic achievement test scores to genetic differences between Blacks and Whites. Their book raised a firestorm of criticism that, ironically, has been successful in discrediting the genetic explanation as the sole or even main source of Black-White disparity. ${ }^{37}$

The standard estimate of heritability in behavioral genetics is $50 \% .{ }^{38}$ That is, $50 \%$ of the variability across persons in measured behaviors is estimated to be due to genes inherited from parents. Genes do not fully determine life outcomes. Neither do environments. Extreme claims about genetic determinism are clearly at odds with the evidence. So are extreme claims about environmental influences.

A striking example of the power of culture and environment is the gap in achievement test scores between genetically very similar Ashkenazi and Sephardic Jews in Israel. They are roughly $2 / 3$ of the gap in measured achievement between Blacks and Whites. ${ }^{39}$ The results from the intervention analyses discussed below strengthen the conclusion that environments shape outcomes and that they can be favorably improved.

Schooling raises the scores on achievement tests, which are tests that measure acquired knowledge along with "pure ability." Herrnstein and Murray used such an achievement test to measure intelligence. ${ }^{40}$ In addition, personality traits account for a substantial portion of the variability in the test score they used (which is the test score used in the analyses of Tables 1 and 2). ${ }^{41}$ Furthermore, interventions can enhance these traits.

The lessons of modern genetics are more subtle. The Nature vs. Nurture debate is over. ${ }^{42}$ Environmental conditions affect gene expression. Substantial evidence shows that early adversity affects biology and human development. Disadvantage literally gets under the skin and serves to shape the biology of disadvantaged children. ${ }^{43}$

The gene expression of genetically identical (monozygotic) twins has been studied. Environmental conditions trigger gene expression. ${ }^{44}$ Early environments are especially important. By age three, and certainly by age 50, the genetic expressions of "identical" twins differ as a result of their separate life experiences. This produces diverse behavioral and life outcomes within twin pairs. ${ }^{45}$

One study of gene-environment interactions shows that a variant of the MAOA gene predicts male conduct disorder and violence. However, the variant of the gene is most strongly expressed when child-rearing environments are adverse. Many other such geneenvironment interactions have been documented. ${ }^{46}$ The heritability of traits is substantially modified by the environment in which a child is raised. Children from less advantaged environments display diminished heritability of traits (30\% versus the standard $50 \%$ in behavioral genetics). ${ }^{47}$

Recent research establishes the validity of a form of Lamarckian evolution. Adversity is partly heritable. The adversity of the mother affects the gene expression of the child. Early 
environmental influences are especially important. ${ }^{48,49}$ History gets embedded in the expression of our genes. Failing to address early disadvantage produces a biological legacy that persists over generations. ${ }^{50}$

\section{How Best to Foster Skills}

What are the best ways to promote skills and reduce achievement gaps? Is it fixing schools? Is it supplementing the resources of families? It is both but with proper timing and measure. In the current fiscal climate, we cannot afford to repeat the mistakes of the War on Poverty and try to do everything. Prioritization is essential. Bad schools should be improved, but supplementing the parenting resources of disadvantaged families is an effective and less commonly understood way to improve educational outcomes.

One year after the Moynihan report circulated, the eminent sociologist James Coleman and his colleagues ${ }^{51}$ produced a study that challenged a central premise of American policy. The report showed that families and not the attributes of schools, the focus of much current public policy, determined the success of children in schools as measured by their performance on achievement tests.

After 40 years, the wisdom of Coleman and Moynihan has not yet been incorporated into American public policy. Yet, their message is clear. Family matters, American families are in trouble, and families are the main drivers of the success of children in schools.

At the present time, our social policy for fostering the skills of children largely focuses on improving schools. This strategy is politically palatable because it avoids the charge of "blaming the victim" and avoids any hint of intrusion into the sanctity of the family-a deeply held American value. At the same time, a strictly school-based policy ignores the evidence about the inequality present when children enter school. ${ }^{52}$ School-based policy does not attack skill gaps at their source - the lack of family resources for effective early childhood development.

The evidence on the success of school reforms is at best mixed. ${ }^{53}$ For example, not all charter schools are more effective than public schools. The latest evaluations show that $20 \%$ are better; $20 \%$ are worse and most $-60 \%$-about the same. ${ }^{54}$ Moreover, parental involvement and encouragement appear to be essential ingredients of successful charters.

Surely we can and should improve our schools. But, in light of the evidence from the Coleman Report and a vast body of scholarly literature that arose from that study, improving the schools by hiring better teachers, monitoring their performance, reducing classroom sizes, and improving access to the Internet is unlikely to be enough to eliminate gaps, although much recent public policy and philanthropic activity is predicated on that assumption. Schools work with what parents bring them and they are more successful if parents support them.

Part of the hesitation in adopting any family policy is that we do not fully understand all of the mechanisms of family influence. How do families produce advantage and disadvantage across the generations? Research is active in this area. Much remains to be known.

However, we know for certain that parents do a lot more than pass on their genes, and good parenting matters a lot.

\section{Family Environments for All American Children Have Worsened}

By many measures, family environments have worsened for children of all race and ethnic groups, although the severity of the problem differs greatly among groups. Figure 2 shows 
that in 2010 almost $30 \%$ of all American children live with a single parent. The greatest source of growth in the past 30 years has been in the category "never married." Numerous studies in economics, demography and sociology confirm Moynihan's concern that the child rearing environments of children in single parent families are compromised and with them child outcomes. ${ }^{55}$

\section{The Consequences of Early Adversity}

The central role of the family in producing child skills and in forming character has been recognized since time immemorial. American public policy has to shift to acknowledge that the core skills needed for success in life are formed before children enter school. The main lesson of Figure 1-that gaps in child test scores open up early and persist and that schools contribute little to these gaps-needs to be acted on.

Corresponding to gaps in performance, a gap has emerged between the environments of children of more educated women and the environments of children of less educated women. Sara McLanahan refers to this as the "Great Divide" and notes that the children of the advantaged and of the disadvantaged face "Diverging Destinies." 56

Fewer than ten percent of college educated women bear children out of wedlock. More educated women marry later and marry more educated men. They work more. They have more resources, have fewer children, and provide much richer child rearing environments that produce dramatic differences in a child's vocabulary, intellectual performance, nurturance, and discipline. ${ }^{57}$ These advantages are especially pronounced for children of two parent stable marriages ${ }^{58}$ Children of such marriages appear to be at a major advantage compared to children from other unions.

Even though they work more than less educated women, college-educated mothers devote more time to child rearing than less-educated mothers, especially in providing child enrichment activities. ${ }^{59}$ They spend more time reading to children and less time watching television with them.

Disadvantaged mothers, as a group, talk less to their children and are less likely to read to them daily. Exposure to this type of parenting leads to substantial differences in the verbal skills of disadvantaged children when they start school. ${ }^{60}$ Disadvantaged mothers encourage their children less and tend to adopt harsher parenting styles. Disadvantaged parents tend to be less engaged with their children's school work. ${ }^{61}$ The environments provided by teenage mothers are particularly adverse. ${ }^{62} \mathrm{Fetal}$ alcohol ingestion alone, which is more frequent with teenage and less educated mothers, appears to have substantial deleterious consequences on adult outcomes. ${ }^{63}$ A central premise of Geoffrey Canada's much discussed Harlem Children's Zone project, and especially his Baby College, is that parental engagement from the earliest years is an essential aspect of creating success for disadvantaged children. ${ }^{64}$

Child poverty is not solely or even mainly about access to financial resources. ${ }^{65}$ Johnson's War on Poverty made the mistake of focusing on remediating financial poverty. An overwhelming body of evidence suggests that parenting plays a crucial role-what parents do and do not do; how they interact with and supplement the lives of their children, especially their early lives. The true measure of child affluence and poverty is the quality of parenting. A lone mother living in financial poverty can create a stimulating early environment for her child. ${ }^{66}$ 


\section{Supplement Disadvantaged Families, Don't Blame Them}

How to best aid struggling families? How to produce a cost-effective child skill formation policy that recognizes the trends affecting many American families? Many great minds over the ages have recognized that the family is a major source of social inequality. They have proposed replacing the family to reduce inequality. That policy has been tried with disastrous consequences. ${ }^{67}$ There is no good substitute for a mother's love and care.

Public policy needs to be reformulated to recognize the dynamics of skill formation-the biology and neuroscience that shows that skills beget skills; that success breeds success; that disadvantage gets embodied into the biology of the child and retards the development of children in terms of their health, character, and smarts.

While we do not yet know all of the mechanisms through which families influence their children, we know enough to suggest the broad contours of an effective child development strategy. Supplementing the early years of disadvantaged children addresses a major source of inequality. Many programs that supplement the child rearing resources of families are effective. While much remains to be known, much is also known.

For example, the Perry preschool program targeted disadvantaged, subnormal IQ African American preschoolers in a city just outside Detroit. ${ }^{68}$ For two years, the program taught children to plan, execute and evaluate daily projects in a structured setting. It fostered social skills. There were weekly home visits to encourage parenting. The Perry Program was evaluated using random assignment with long-term follow-up for 40 years. Rates of return are $7-10 \%$ per annum - higher than the return on equity over the post-war period 19452008 and before the recent market meltdown. ${ }^{69}$ The Perry program did not boost the IQs of participants. It worked by fostering soft skills. ${ }^{70}$

These and other successful child development programs work because they start early. Benefits include enhanced school readiness, and reduced burdens on the schools for special education. They produce benefits in the teen years with better health behaviors, reduced teenage pregnancy and lower dropout rates. They promote higher adult productivity and self-sufficiency. They supplement the family by working with both the parent and the child. They provide a strong boost to character skills that matter. Successful programs offer a lifeline of family supplementation for disadvantaged families. They engage the parents, are voluntary, and do not impair the sanctity of the family. Disadvantaged families of all race groups gladly take up opportunities to enhance the lives of their children. Most mothers, however disadvantaged, want the best for their children. The voluntary nature of these programs avoids coercion and condescension and promotes dignity.

The logic underlying enrichment of the early environments of disadvantaged children is based on a deeper understanding of the life cycle of skill formation than was available to the architects of the War on Poverty. More motivated and healthier children are better learners. The process is dynamic and feeds back on itself-academic success and social success promote greater self-confidence and a willingness of children to explore.

A strategy that places greater emphasis on parenting resources directed to the early years is a strategy that prevents rather than remediates problems. It supplements families and makes them active participants in the process of child development.

Remediation strategies as currently implemented are much less effective. This is the flip side of the argument for early intervention. Many skills that are malleable in the early years are much less so in the teenage years. As a consequence, remediating academic and social deficits in the teenage years is much more costly. Even at great cost, remediation policies 
have not been effective and certainly earn annual rates of return far below the 7-10\% found for the Perry Program. ${ }^{71}$

For high quality early childhood interventions, there are none of the trade-offs between equity and efficiency that plague most public policies. Early interventions produce broadly based benefits and reduce social and economic inequality. At the same time they promote productivity and economic efficiency. They are both fair and efficient.

In contrast, the school-focused No Child Left Behind program ${ }^{72}$ diverts teaching away from fostering other skills that matter for success in life besides tested math and reading. Because it ignores inequality at the starting gate, No Child Left Behind leaves many children behind.

\section{Dynamic Synergies and the Timing of Effective Interventions}

High quality early childhood programs are investments with rates of returns far higher than those found for most governmentally provided skills programs. Figure 3 summarizes the evidence from a large body of research in economics and developmental psychology. The figure plots the rate of return to investment for an extra dollar of investment in the early years, in preschool, in school and in job training for a person who has an initial (low) common baseline investment at all ages. The return to investment at the earliest ages is high because it creates the foundation of skills that make later investment productive. ${ }^{73}$ This pattern is a manifestation of dynamic synergism — what economists call "dynamic complementarity." For example, children who enter school with character and cognitive skills gain more from formal education. ${ }^{74}$

Early investment percolates throughout the life cycle. If the base is not strong, and has been compromised by early family disadvantage, skill investments at later ages are much less productive. This is due to the lessened malleability of older children and adults compared to that of young children.

The negative side of dynamic complementarity is that there is an equity-efficiency tradeoff for skill investment programs targeted toward disadvantaged adolescents and adults who lack a strong skill base. Remediation in the late adolescent and adult years to achieve the same level of competence is much more costly. This feature of dynamic complementarity accounts for the sorry record of a variety of skill enhancement programs, launched in the War on Poverty, that still receive substantial public support. ${ }^{76}$ Current policy does not heed the wisdom inherent in Figure 3. We overinvest in attempting to remediate the problems of disadvantaged adolescents and underinvest in the early years of disadvantaged children.

In contrast to the $7-10 \%$ per annum earned by the Perry program and other early childhood programs, returns on many other skill enhancement programs are much lower. They are certainly lower for public job training, criminal rehabilitation programs, adult literacy programs, and a variety of other later life remediation programs targeting disadvantaged adolescents and young adults with low cognitive and character skills. ${ }^{77}$ For example, a recent evaluation of the Job Corps showed meager earnings benefits a negative rate of return. ${ }^{78}$ Reducing pupil-teacher ratios in schools also has a negative rate of return. ${ }^{79} \mathrm{We}$ need to listen to the logic of developmental biology to devise strategies to reduce disparities in parenting across all racial and ethnic groups.

\section{Engage the Private Sector}

How can we fund such programs? Times are hard and government budgets are strained. Nonetheless, it would be possible to fund effective new programs if they replaced the numerous ineffective programs currently in place. Few governmental programs of any sort 
would meet the standard set by the high rates of return earned by childhood programs. As high quality early childhood programs are implemented, the budgetary burden of remediation will be lessened.

Engaging the private sector-philanthropic, community and religious organizationsbolsters the resource base supporting early childhood. Bringing in diverse partners encourages experimentation with new approaches that build on the success of templates like Perry and the Abecedarian program. ${ }^{80}$ Educare is one promising program that fosters public and private partnerships. ${ }^{81}$ Engaging diverse groups encourages development of culturally and religiously sensitive intervention programs that respect the sanctity of the family and the diversity of values that characterize modern American society.

\section{A New Strategy Based on New Knowledge}

In contemporary American society, the racial gap in achievement is primarily due to gaps in skills. Modern society is based on skills, and inequality in achievement across all race and ethnic groups is primarily due to inequality in skills. Both cognitive and personality skills determine life success.

Families are major producers of skills. They do much more than pass along their genes. Inequality in skills and schools is strongly linked to inequality in family environments. While the exact mechanisms through which families produce skills are actively being investigated, a lot is already known. Parenting matters. The true measure of child poverty and advantage is the quality of parenting a child receives, not just the money available to a household.

A growing fraction of American children across all race and ethnic groups is being raised in dysfunctional families. The growing contrast between the early environments of advantaged and disadvantaged children threatens to create greater inequality in the next generation of Americans from an already high level.

We have learned a lot about how to foster skills since the 1960s when the War on Poverty attempted to remediate skills deficits of people of all ages and developmental stages. The science of skill formation shows how skill begets skill.

Investments that foster early life skills enhance the productivity of investment at later ages. They support the schools and enhance the productivity of adult job training. Because of the percolation effects of early investment due to the dynamic complementarity of skill formation, policies that attack inequality at its early source are cost-effective. They promote equality and, at the same time, promote economic efficiency. There is no equity-efficiency tradeoff for such policies.

The malleability and plasticity characteristic of young children declines with age. This effect is what makes investment in disadvantaged, low skilled young adults so difficult. To achieve the same adult outcomes, later life remediation for disadvantage is far more costly than early life prevention. There is an equity-efficiency tradeoff for later-life remediation activities. As early life programs pay off, the budgets spent on remediation can be substantially reduced.

Our current policies to reduce achievement gaps ignore these simple truths. America currently places too much emphasis on improving what goes on in schools compared to improving what goes on in families. Supplementing the parenting resources of disadvantaged Americans will bolster American schools and enhance the effectiveness of school reforms. It will lower the burden of remediation. A comprehensive, cost-effective policy to enhance the skills of disadvantaged children of all racial and ethnic backgrounds 
through voluntary, culturally sensitive support for parenting is a politically and economically palatable strategy.

\section{Supplementary Material}

Refer to Web version on PubMed Central for supplementary material.

\section{Acknowledgments}

This research was supported by the American Bar Foundation, NICHD R01 HD065072, NICHD R01 HD054702, the Institute for New Economic Thinking (INET), the J.B. \& M.K. Pritzker Family Foundation, the Buffett Early Childhood Fund, the MacArthur Foundation, the Spencer Foundation and an anonymous foundation. The views expressed here are those of the author and not necessarily those of the funders. I thank Steve Durlauf, Miriam Gensowski, Lynne Pettler Heckman, Tim Kautz, Nick Mader, Seong Hyeok Moon, Rich Neimand, Bob Pollak, and Paul Tough for their very helpful comments on drafts of the paper. Molly Schnell gave devoted research assistance and helpful commentary. I thank Nick Mader and Seong Moon for their help in producing some of the supporting materials for this paper.

\section{References}

1. See Donohue, John J.; Heckman, James J. Continuous Versus Episodic Change: The Impact of Civil Rights Policy on the Economic Status of Blacks. Journal of Economic Literature. 1991; 29(4).

2. See Butler, Richard; Heckman, James J. Hausman LF. The Impact of the Government on the Labor Market Status of Black Americans: A Critical Review. Equal Rights and Industrial Relations. 1977Industrial Relations Research AssociationMadison, WI.; Chandra, Amitabh. Is the Convergence of the Racial Wage Gap Illusory?. 2003National Bureau of Economic Research.; and Heckman, James J.; LaFontaine, Paul A. The American High School Graduation Rate: Trends and Levels. Review of Economics and Statistics. 2010; 92(2).

3. Wilson, William J. The Truly Disadvantaged: The Inner City, the Underclass, and Public Policy. 1987University Of Chicago PressChicago; Wilson, William J. More Than Just Race: Being Black and Poor in the Inner City. 2009W. W. Norton \& CompanyNew York.

4. See Heckman, LaFontaine.

5. See Heckman, James J.; LaLonde, Robert J.; Smith, Jeffrey A. Ashenfelter, Orley; Card, DavidThe Economics and Econometrics of Active Labor Market Programs. Handbook of Labor Economics. 1999; vol. 3ANorth-HollandNew York.

6. See Ellwood, David; Jencks, Christopher. Neckerman, Kathryn M.The Uneven Spread of SingleParent Families: What Do We Know? Where Do We Look for Answers? Social Inequality. 2004Russell Sage FoundationNew York.

7. McLanahan, Sara. Diverging Destinies: How Children Are Faring under the Second Demographic Transition. Demography. 2004; 41(4)

8. Moynihan, Daniel P. Employment, Income, and the Ordeal of the Negro Family. Bobbs-Merrill Company; Indianapolis: 1965. See http://www.dol.gov/oasam/programs/history/webid-meynihan.htm

9. See the essays in the Annals of the American Academy of Political and Social Science (2009, Vol. 621, Issue 1) and, especially, the introductory essay by Massey, Douglas S.; Sampson, Robert J. Moynihan Redux: Legacies and Lessons. The ANNALS of the American Academy of Political and Social Science. 2009; 621(1); Wilson, William Julius. The Moynihan Report and Research on the Black Community. The ANNALS of the American Academy of Political and Social Science. 2009; 621(1).

10. See the Web Appendix

11. See the gaps documented in the Web Appendix and the recent review by Fryer, Roland. Racial Inequality in the 21st Century: The Declining Significance of Discrimination. Handbook of Labor Economics. 2010; Volume 4 Forthcoming in the. .

12. I use a procedure developed by Neal, Derek A.; Johnson, William R. Jencks, Christopher; Phillips, MeredithBasic Skills and the Black-White Earnings Gap. The Black-White Test Score Gap. 1998Brookings Institution PressWashington, D.C.. 
13. Cameron, Stephen V.; Heckman, James J. The Dynamics of Educational Attainment for Black, Hispanic, and White Males. Journal of Political Economy. 2001; 109(3)

14. See Ibid. The results are similar for men and women so I only report the pooled results

15. See Carneiro, Pedro; Heckman, James J.; Masterov, Dimitriy V. Nelson R, Nielsen L. Understanding the Sources of Ethnic and Racial Wage Gaps and Their Implications for Policy. Handbook of Employment Discrimination Research: Rights and Realities. 2005SpringerNew York. and Carneiro, Pedro; Heckman, James J.; Masterov, Dimitriy V. Labor Market Discrimination and Racial Differences in Pre-Market Factors. Journal of Law and Economics. 2005; 48(1).

16. Pager, Devah. The Use of Field Experiments for Studies of Employment Discrimination: Contributions, Critiques, and Directions for the Future. The ANNALS of the American Academy of Political and Social Science. 2007; 609

17. See Heckman, James J. Detecting Discrimination. Journal of Economic Perspectives. 1998; 12(2).

18. Fryer reports ability adjusted disparities for many other outcomes. In virtually all cases he considers, measured gaps are diminished (but not fully eliminated) by accounting for ability

19. See the figures in the Web Appendix

20. See Jencks, Christopher. Jencks, Christopher; Phillips, MeredithRacial Bias in Testing. The BlackWhite Test Score Gap. 1998Brookings Institution PressWashington, D.C.; Sackett, Paul R.; Borneman, Matthew J.; Connelly, Brian S. High Stakes Testing in Higher Education and Employment: Appraising the Evidence for Validity and Fairness. American Psychologist. 2008; 63(4).

21. Carneiro, Heckman, Masterov. Understanding the Sources of Ethnic and Racial Wage Gaps and Their Implications for Policy. ; Carneiro, Heckman, Masterov. Labor Market Discrimination and Racial Differences in Pre-Market Factors.

22. See Carneiro, Heckman, Masterov. Understanding the Sources of Ethnic and Racial Wage Gaps and Their Implications for Policy. ; Carneiro, Heckman, Masterov. Labor Market Discrimination and Racial Differences in Pre-Market Factors.

23. Steele, Claude M.; Aronson, Joshua. Stereotype Threat and the Test Performance of Academically Successful African Americans. In: Jencks, C.; Phillips, M., editors. The Black-White Test Score Gap. Brookings Institution Press; Washington, D.C.: 1998.

24. See Sackett, Paul R.; Hardison, Chaitra M.; Cullen, Michael J. On Interpreting Stereotype Threat as Accounting for African American-White Differences on Cognitive Tests. The American Psychologist. 2004; 59(1).

25. Koretz, Daniel M. Measuring Up: What Educational Testing Really Tells Us. 2008Harvard University PressCambridge, MA; Rothstein, Richard; Jacobsen, Rebecca; Wilder, Tamara. Grading Education: Getting Accountability Right. 2008Economic Policy Institute and Teachers College PressNew York.

26. Almlund, Mathilde; Duckworth, Angela L.; Heckman, James J.; Kautz, Tim. Personality Psychology and Economics. In: Hanushek, Eric A.; Machin, S.; Wößmann, L., editors. Handbook of the Economics of Education. Elsevier; Amsterdam: 2011. forthcoming

27. Safire, William. New York Times. Aug 13. 1989 On Language; the Elision Fields.

28. See the evidence summarized in Almlund, Duckworth, Heckman, Kautz.

29. Ibid.

30. See the evidence cited in Carneiro, Pedro; Heckman, James J. Heckman, James J.; Krueger, Alan B.; Friedman, Benjamin M.Human Capital Policy. Inequality in America: What Role for Human Capital Policies?. 2003MIT PressCambridge, MA; Cunha, Flavio; Heckman, James J.; Lochner, Lance J.; Masterov, Dimitriy V. Hanushek, Eric A.; Welch, FrankInterpreting the Evidence on Life Cycle Skill Formation. Handbook of the Economics of Education. 2006; vol. 1NorthHollandAmsterdam.

31. See Lareau, Annette. Home Advantage: Social Class and Parental Intervention in Elementary Education (Second ed.). 2000Rowman and LIttlefield Publishers, Inc.Lanham, MD.

32. Source: Brooks-Gunn, Jeanne; Cunha, Flavio; Duncan, Greg; Heckman, James J.; Sojourner, Aaron. A Reanalysis of the IHDP Program. 2006Infant Health and Development Program, Northwestern UniversityUnpublished manuscript. 
33. It is not possible to reliably measure cognition before age 3. See Lewis, Michael; McGurk, Harry. Evaluation of Infant Intelligence. Science. 1972; 178(4066).

34. See the evidence summarized in Cunha, Heckman, Lochner, Masterov. .

35. See the evidence summarized in Carneiro, Heckman. Human Capital Policy. ; Cunha, Heckman, Lochner, Masterov. ; Heckman, James J. Schools, Skills and Synapses. Economic Inquiry. 2008; 46(3).

36. Similar gaps arise when classifying children by various combinations of maternal ability, longterm family income, and material education. See the Web Appendix.

37. See, e.g., Heckman, James J. Lessons from the Bell Curve. Journal of Political Economy. 1995; 103(5); Devlin B, Feinberg S, Resnick D, Roeder K. Intelligence, Genes, and Success: Scientists Respond to the Bell Curve. 1997Springer, CopernicusNew York.

38. Rowe, David C. The Limits of Family Influence: Genes, Experience, and Behavior. Guilford Press; New York NY: 1994.

39. See Rubinstein, Yona; Brenner, Dror. Pride and Prejudice: Evidence from the 'Promised Land'. 2010Brown UniversityUnpublished Manuscript. Note, however, that there is some small amount of genetic variation across the two groups.

40. See Winship, Christopher; Korenman, Sanders. Devlin B, Feinberg S, Resnick D, Roeder K. Does Staying in School Make You Smarter? The Effect of Education on IQ in the Bell Curve. Intelligence, Genes, and Success: Scientists Respond to the Bell Curve. 1997Springer, CopernicusNew York; Neal, Johnson. ; Hansen, Karsten T.; Heckman, James J.; Mullen, Kathleen J. The Effect of Schooling and Ability on Achievement Test Scores. Journal of Econometrics (12). 2004; 121.

41. See Borghans, Lex; Golsteyn, Bart H. H.; Heckman, James J.; Humphries, John Eric. IQ, Achievement, and Personality. 2010University of Chicago, Department of Economics. See also the evidence in Almlund, Duckworth, Heckman, Kautz. .

42. Ridley, Matt. Nature Via Nurture: Genes, Experience, and What Makes Us Human. First ed.. Fourth Estate; New York, NY: 2003.

43. See the essays in the Annals of the New York Academy of Sciences. Issue: The Biology of Disadvantage. 2010; 1186.

44. Caspi, Avshalom; McClay, Joseph; Moffitt, Terrie E.; Mill, Jonathan; Martin, Judy; Craig, Ian W.; Taylor, Alan; Poulton, Richie. Role of Genotype in the Cycle of Violence in Maltreated Children. Science. 2002; 297(5582)

45. See Fraga, Mario F.; Ballestar, Esteban; Paz, Maria F.; Ropero, Santiago; Setien, Fernando; Ballestar, Maria L.; Heine-Suñer, Damia; Cigudosa, Juan C.; Urioste, Miguel; Benitez, Javier; Boix-Chornet, Manuel; Sanchez-Aguilera, Abel; Ling, Charlotte; Carlsson, Emma; Poulsen, Pernille; Vaag, Allan; Stephan, Zarko; Spector, Tim D.; Wu, Yue-Zhong; Plass, Christoph; Esteller, Manel. Epigenetic Differences Arise During the Lifetime of Monozygotic Twins. Proceedings of the National Academy of Sciences of the United States of America. 2005; 102(30).

46. See Moffitt, Terrie E. Gene-Environment Interaction in Problematic and Successful Aging, Unpublished manuscript, Duke Institute for Genome Sciences and Policy, Duke University. Presented at the Workshop on Genetic Methods and Life Course DevelopmentFebruary 11-12, 2008National Institute on AgingBethesda, MD. and the figures posted on the display Web site for the Marshall Lecture at http://jenni.uchicago.edu/Milan_2008/.

47. Turkheimer, Eric; Haley, Andreana; Waldron, Mary; D'Onofrio, Brian; Gottesman, Irving I. Socioeconomic Status Modifies Heritability of IQ in Young Children. Psychological Science. 2003; 14(6)

48. Champagne, Frances A.; Curley, James P. How Social Experiences Influence the Brain. Current Opinion in Neurobiology. 2005; 15; Champagne, Frances A.; Weaver, Ian C. G.; Diorio, Josie; Dymov, Sergiy; Szyf, Moshe; Meaney, Michael J. Maternal Care Associated with Methylation of the Estrogen Receptor-Alpha1b Promoter and Estrogen Receptor-Alpha Expression in the Medial Preoptic Area of Female Offspring. Endocrinology. 2006; 147(6).

49. Stephen Suomi reports parallel findings on genetic moderation of environmental influences for rhesus monkeys that have 95 percent of human genes. See Suomi, Stephen J. Keating, Daniel P.; Hertzman, ClydeDevelopmental Trajectories, Early Experiences, and Community Consequences: 
Lessons from Studies with Rhesus Monkeys. Developmental Health and the Wealth of Nations: Social, Biological, and Educational Dynamics. 1999The Guilford Press; Suomi, Stephen J. GeneEnvironment Interactions and the Neurobiology of Social Conflict. Annals of the New York Academy of Sciences. 2003; 1008.

50. Kaati, Gunnar; Bygren, Lars Olov; Pembrey, Marcus; Sjostrom, Michael. Transgenerational Response to Nutrition, Early Life Circumstances and Longevity. Eur J Hum Genet. 2007; 15(7); Jablonka, Eva; Raz, Gal. Transgenerational Epigenetic Inheritance: Prevalence, Mechanisms, and Implications for the Study of Heredity and Evolution. The Quarterly Review of Biology. 2009; 84(2); Kuzawa, Christopher W.; Sweet, Elizabeth. Epigenetics and the Embodiment of Race: Developmental Origins of Us Racial Disparities in Cardiovascular Health. American Journal of Human Biology. 2009; 21(1); Gluckman, Peter D.; Hanson, Mark A.; Beedle, Alan S. NonGenomic Transgenerational Inheritance of Disease Risk. BioEssays. 2007; 29(2).

51. See Coleman, James S. Equality of Educational Opportunity. 1966U.S. Dept. of Health, Education, and Welfare, Office of EducationWashington, DC.

52. See Neuman, Susan B. Changing the Odds for Children at Risk: Seven Essential Principles of Educational Programs That Break the Cycle of Poverty. 2009Praeger PublishersWestport, CT.

53. See Ravitch, Diane. The Death and Life of the Great American School System: How Testing and Choice Are Undermining Education. 2010Basic BooksNew York, NY; Gleason, Philip; Clark, Melissa; Tuttle, Christina; Dwoyer, Emily. The Evaluation of Charter School Impacts. 2010National Center for Education Evaluation and Regional Assistance, Institute of Education Sciences, U.S. Department of Education.

54. Ravitch.

55. See, e.g., McLanahan. ; McLanahan, Sara; Sandefur, Gary D. Growing up with a Single Parent: What Hurts, What Helps. 1994Harvard University PressCambridge, MA. Ginther and Pollack show that children living in blended families (without both biological parents present) do about the same as children of lone parents. See Ginther, Donna K.; Pollak, Robert A. Family Structure and Children's Educational Outcomes: Blended Families, Stylized Facts, and Descriptive Regressions. Demography. 2004; 41(4).

56. McLanahan. Diverging Destinies: How Children Are Faring under the Second Demographic Transition.

57. Hart, Betty; Risley, Todd R. American Parenting of Language-Learning Children: Persisting Differences in Family-Child Interactions Observed in Natural Home Environments. Developmental Psychology. 1992; 28(6); Hart, Betty; Risley, Todd R. Meaningful Differences in the Everyday Experience of Young American Children. 1995P.H. BrookesBaltimore, MD.

58. See McLanahan, Sara. Fragile Families and the Reproduction of Poverty. 2008Center for Research on Child Wellbeing and Fragile FamiliesPrinceton, NJ.

59. Bianchi, Suzanne M.; Robinson, John P.; Milkie, Melissa A. Changing Rhythms of American Family Life. Anderton, Douglas L.; Clawson, Dan; Gerstel, Naomi; Misra, Joya; Stokes, Randall G.; Zussman, Robert, editors. Russell Sage Foundation; New York, NY: 2006.

60. See the evidence on school readiness cited in Neuman. See also Moilanen, Kristin L.; Shaw, Daniel S.; Dishion, Thomas J.; Gardner, Frances; Wilson, Melvin. Predictors of Longitudinal Growth in Inhibitory Control in Early Childhood. Social Development. 2009; 19(2).

61. Ferguson, Ronald. Why America's Black-White School Acheivement Gap Persists. In: Loury, Glenn C.; Modood, Tariq; Teles, Steven M., editors. Ethnicity, Social Mobility, and Public Policy. Cambridge University Press; New York, NY: 2005. Lareau.

62. See Francesconi, Marco. Adult Outcomes for Children of Teenage Mothers. 2007IZA; Levine, Judith A.; Pollack, Harold; Comfort, Maureen E. Academic and Behavioral Outcomes among the Children of Young Mothers. Journal of Marriage and Family. 2001; 63(2).

63. See Nilsson, J. Peter Does a Pint a Day Affect Your Child's Pay? The Effect of Prenatal Alcohol Exposure on Adult Outcomes. 2008Institute for Labour Market Policy Evaluation; Streissguth, Ann. Offspring Effects of Prenatal Alcohol Exposure from Birth to 25 Years: The Seattle Prospective Longitudinal Study. Journal of Clinical Psychology in Medical Settings. 2007; 14(2); Zhang, Xingqi; Sliwowska, Joanna H.; Weinberg, Joanne. Prenatal Alcohol Exposure and Fetal Programming: Effects on Neuroendocrine and Immune Function. Experimental Biology and Medicine. 2005; 230(6). 
64. Tough, Paul. Whatever It Takes: Geoffrey Canada's Quest to Change Harlem and America. First Mariner Books; New York, NY: 2009.

65. Mayer, Susan E. What Money Can't Buy: Family Income and Children's Life Chances. Harvard University Press; Cambridge, MA: 1997.

66. When an American Indian tribe substantially enhanced its income by opening a casino, child behavioral outcomes improved dramatically but not uniformly. Most of the improvement arose in children whose parents improved their parenting. See Costello, E. Jane; Compton, Scott N.; Keeler, Gordon; Angold, Adrian. Relationships between Poverty and Psychopathology: A Natural Experiment. Journal of the American Medical Association. 2003; 290(15).

67. U.S. Congress. Senate Committee on Labor and Public Welfare. Special Sub-committee on Indian Education, Indian Education: A National Tragedy --A National Challenge (Senate Report 91-501). 91st Congress, 1st Sess.; November 3, 1969;

68. Schweinhart, LJ.; Barnes, Helen V.; Weikart, David. Significant Benefits: The High-Scope Perry Preschool Study through Age 27. High/Scope Press; Ypsilanti, MI: 1993.

69. Heckman, James J.; Moon, Seong Hyeok; Pinto, Rodrigo; Savelyev, Peter A.; Yavitz, Adam Q. The Rate of Return to the Highscope Perry Preschool Program. Journal of Public Economics. 2010; 94(1-2)

70. Heckman, James J.; Malofeeva, Lena; Pinto, Rodrigo; Savelyev, Peter A. Understanding the Mechanisms through Which an Influential Early Childhood Program Boosted Adult Outcomes. Department of Economics, University of Chicago; 2010.

71. See the evidence in Heckman, LaLonde, Smith. The Economics and Econometrics of Active Labor Market Programs. ; Cunha, Heckman, Lochner, Masterov. .

72. Rothstein; Jacobsen; Wilder.

73. See Cunha, Flavio; Heckman, James J. The Technology of Skill Formation. American Economic Review. 2007; 97(2).

74. Duncan, Greg J.; Dowsett, Chantelle J.; Claessens, Amy; Mugnuson, Katherine; Huston, Aletha C.; Klebanov, Pamela; Pagani, Linda S.; Feinstein, Leon; Engel, Mimi; Brooks-Gunn, Jeanne; Sexton, Holly; Duckworth, Kathryn; Japel, Crista. School Readiness and Later Achievement. Developmental Psychology. 2007; 43(6); Brooks-Gunn, Jeanne; Markman, Lisa B. The Contribution of Parenting to Ethnic and Racial Gaps in School Readiness. The Future of Children. 2005; 15(1).

75. Heckman. Schools, Skills and Synapses.

76. See the evidence in Heckman, LaLonde, Smith. The Economics and Econometrics of Active Labor Market Programs. ; Cunha, Heckman, Lochner, Masterov. Interpreting the Evidence on Life Cycle Skill Formation.

77. See the evidence in Cunha, Heckman, Lochner, Masterov. .

78. See Schochet, Peter Z.; Burghardt, John; McConnell, Sheena. Does Job Corps Work? Impact Findings from the National Job Corps Study. American Economic Review. 2008; 98(5).

79. See the evidence in Cunha, Heckman, Lochner, Masterov. .

80. For discussion of a range of proven programs, see Reynolds, Arthur J.; Rolnick, Arthur J.; Englund, Michelle M.; Temple, Judy A.Childhood Programs and Practices in the First Decade of Life: A Human Capital Integration. 2010Cambridge University PressCambridge, MA.

81. http://www.educareschools.org/pages/index.php?q=node/6 


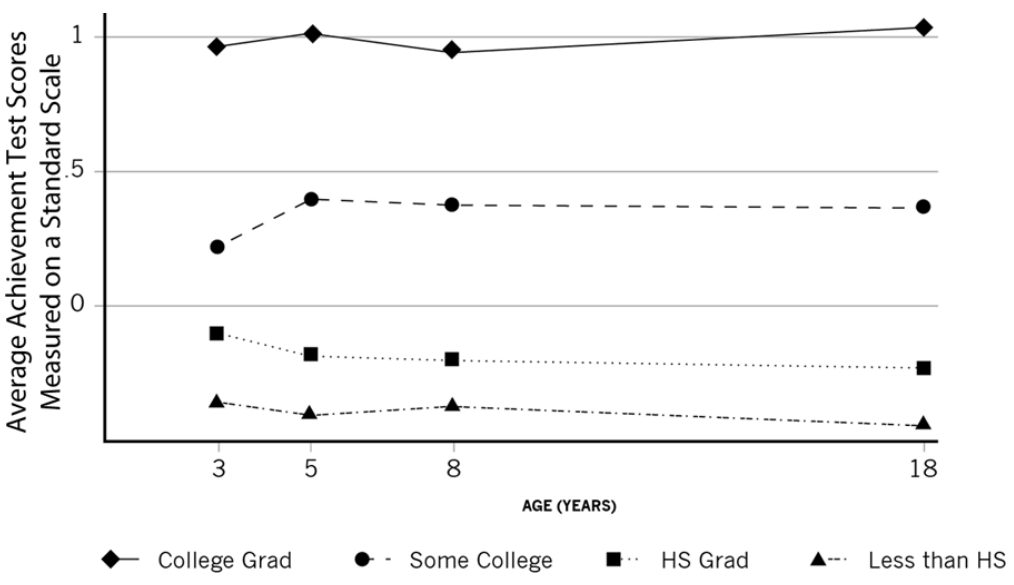

Figure 1. Average Achievement Test Scores of Children by Age by Maternal Education Scores are reported in standardized units (they are transformed to " $Z$ " scores, i.e., normalized scores with unit variance.). ${ }^{32}$ 


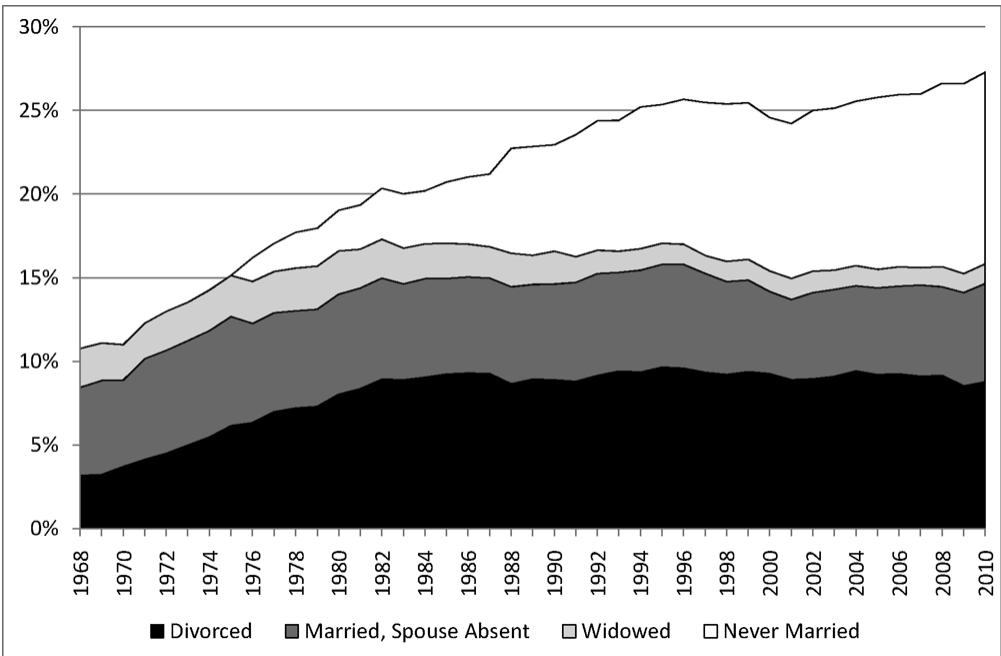

Figure 2. Percent of Children Under 18 Living with One Parent, By Marital Status of the Parent Source: Author's tabulations. 


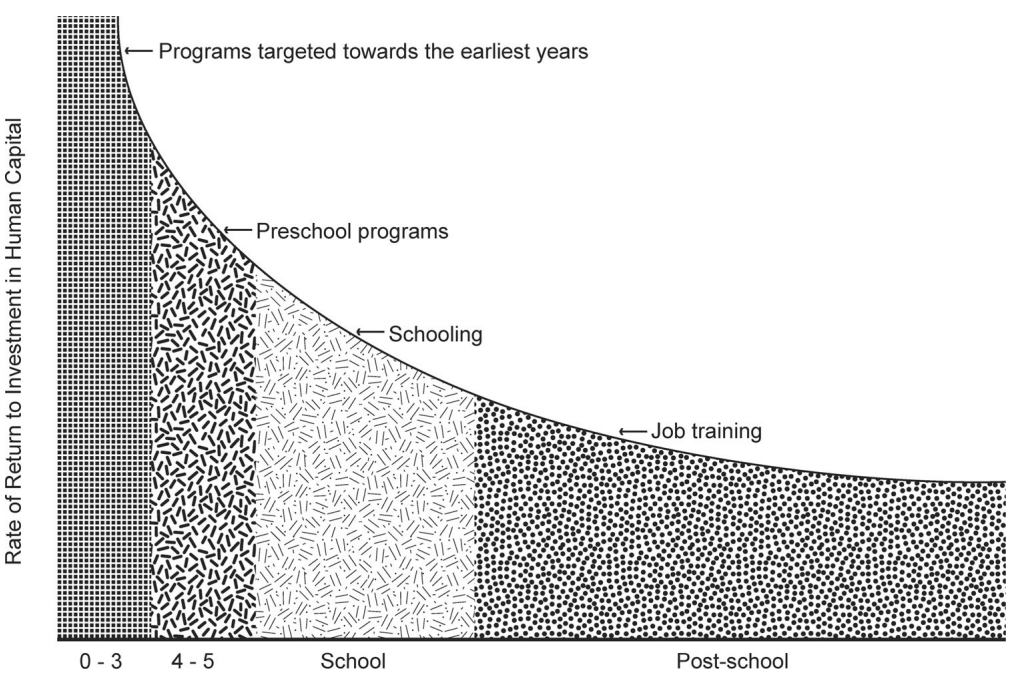

Figure 3. Returns to a unit dollar invested Source: Heckman (2008). ${ }^{75}$ 


\section{Table 1}

Shortfalls in Hourly Wages by Age for Blacks and Hispanics in the Last 20 Years: Actual Disparity and Adjusted for Ability

\begin{tabular}{l|c|c|c|c}
\hline & \multicolumn{2}{|c|}{ Males } & \multicolumn{2}{c}{ Females } \\
\hline & Raw & Adjusted & Raw & Adjusted \\
\hline Black & $-25 \%$ & $-6 \%$ & $-17 \%$ & $12 \%$ \\
\hline Hispanic & $-15 \%$ & $3 \%^{\Delta}$ & $-7 \%$ & $17 \%$ \\
\hline
\end{tabular}

Source: Author's calculations from the National Longitudinal Survey of Youth. For details, see the web appendix (http://jenni.uchicago.edu/understanding_b-w_gap/).

${ }^{4}$

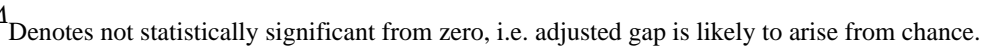




\section{Table 2}

Differences Between College Entry Proportions of Minorities and Whites (mid-1990s)

\begin{tabular}{lcc}
\hline & Black-White & Hispanic-White \\
\hline Actual & -.12 & -.14 \\
Adjusted & .16 & .15 \\
\hline \multicolumn{2}{l}{ Source: Cameron and Heckman (2001). ${ }^{13}$}
\end{tabular}

